\title{
Neuroprotective effects of dehydroepiandrosterone (DHEA) in rat model of Alzheimer's disease
}

\author{
Hanan F. Aly ${ }^{\bowtie}$, Fateheya M. Metwally² and Hanaa H. Ahmed ${ }^{3}$ \\ 1Therapeutical Chemistry Department, National Research Center, Cairo, Egypt; ${ }^{2}$ Environmental and Occupational Medicine Department, National \\ Research Center, Cairo, Egypt; ${ }^{3 H}$ Hormones Department, National Research Center, Cairo, Egypt
}

\begin{abstract}
The current study was undertaken to elucidate a possible neuroprotective role of dehydroepiandrosterone (DHEA) against the development of Alzheimer's disease in experimental rat model. Alzheimer's disease was produced in young female ovariectomized rats by intraperitoneal administration of $\mathrm{AlCl}_{3}(4.2 \mathrm{mg} / \mathrm{kg}$ body weight) daily for 12 weeks. Half of these animals also received orally DHEA ( $250 \mathrm{mg} / \mathrm{kg}$ body weight, three times weekly) for 18 weeks. Control groups of animals received either DHAE alone, or no DHEA, or were not ovariectomized. After such treatment the animals were analyzed for oxidative stress biomarkers such as hydrogen peroxide, nitric oxide and malondialdehyde, total antioxidant capacity, reduced glutathione, glutathione peroxidase, glutathione reductase, superoxide dismutase and catalase activities, antiapoptotic marker $\mathrm{Bcl}-2$ and brain derived neurotrophic factor. Also brain cholinergic markers (acetylcholinesterase and acetylcholine) were determined. The results revealed significant increase in oxidative stress parameters associated with significant decrease in the antioxidant enzyme activities in Al-intoxicated ovariectomized rats. Significant depletion in brain $\mathrm{Bcl}-2$ and brain-derived neurotrophic factor levels were also detected. Moreover, significant elevations in brain acetylcholinesterase activity accompanied with significant reduction in acetylcholine level were recorded. Significant amelioration in all investigated parameters was detected as a result of treatment of Al-intoxicated ovariectomized rats with DHEA. These results were confirmed by histological examination of brain sections. These results clearly indicate a neuroprotective effect of DHEA against Alzheimer's disease.
\end{abstract}

Keywords: Alzheimer's disease, oxidative stress, apoptosis, dehydroepiandrosterone.

Received: 03 March, 2011; revised: 17 August, 2011; accepted: 09 November, 2011; available on-line: 06 December, 2011

\section{INTRODUCTION}

Alzheimer's disease (AD) is a neurodegenerative disorder characterized clinically by progressive memory loss and subsequent dementia. AD proceeds at stages from mild and moderate to severe, and gradually destroys the brain. The pathological hallmarks of AD include accumulation of proteins (a massive accumulation of neurofibrillar tangles and $\beta$-amyloid), loss of neurons and synapses, proliferation of reactive astrocytes in the entorhinal cortex, hippocampus, amy- gdala and association areas of frontal, temporal, parietal and occipital cortex (Grosgen et al., 2010).

It has been reported that aluminum accumulates significantly in the hippocampus following chronic exposure to aluminum. Also, aluminum has been observed in neuritic deposits, $\beta$-amyloid plaques and neurofibrillar tangles in Alzheimer's brain. Chronic aluminum exposure is involved in the impairment of mitochondrial electron transport chain (ETC) and increased production of reactive oxygen species (ROS) (Kumar et al., 2008). Moreover, aluminum promotes the formation of $\beta$-amyloid plaques (Bharathi et al., 2008) and aggregation of tau proteins in Alzheimer's disease (Walton \& Wang, 2009).

Dehydroepiandrosterone (DHEA) and its sulfate metabolite (DHEAS) are the major androgens secreted by the human adrenal gland. A decline in their production is the most characteristic age-related change in the adrenal cortex (Krysiak et al., 2008; Goel \& Cappola, 2011). The integrity of neuroprotection is an important component against the development of cognitive disorders such as AD. DHEAS seems to have some positive metabolic and endocrine effects to delay brain aging by recovering the impairment of neuroprotective growth factors (Luppi et al., 2009; Lazaridis et al., 2011). Also, DHEA has antioxidant, antilipidperoxidative, antiinflammatory and thereby antiaging actions (Kumar et al., 2008). The possibility of using DHEA in management of various diseases has attracted considerable attention over recent years. Whereas DHEA therapy seems to be effective in treating patients with cognitive decline, depression, cardiovascular disease, osteoporosis and sexual dysfunctions, further research is needed to better assess the efficacy and safety of DHEA supplementation in patients with neurodegenerative disorders associated with advanced age (Krysiak et al., 2008). Therefore, it could be hypothesized that DHEA treatment could ameliorate or reduce the severity of symptoms of experimental AD induced in rodents. This could be achieved through measuring oxidative stress biomarkers, antioxidant status, antiapoptotic marker $\mathrm{Bcl}-2$, neurotrophic factor $\mathrm{BDNF}$ and cholinergic markers.

e-mail: hanan abduallah@yahoo.com

Abbreviations: Ach, acetylcholine; AchE, acetylcholinesterase; AD, Alzheimer's disease; $\mathrm{BCl}-2$, antiapoptotic marker B cell lymphoma 2; BDNF, brain-derived neurotrophic factor; DHEA, dehydroepiandrosterone; ETC, electron transport chain; GPx, glutathione peroxidase; GR, glutathione reductas; GSH, reduced glutathione; i.p., intraperitoneally; MDA, malondialdehyde; NOS, nitric oxide synthase; ROS, reactive oxygen species; SOD, superoxide dismutase; TAC, total antioxidant capacity. 


\section{MATERIALS AND METHODS}

Dehydroepiandrosterone and all chemicals were purchased from Sigma Co (USA) and aluminum chloride from BDH Laboratory Supplies, Poole (UK).

Experimental animals. Fifty young adult female Sprague-Dawley rats weighing 100-120 g were obtained from the Animal House Colony of the National Research Center, Giza and acclimated in a specific pathogen-free area at $25 \pm 1{ }^{\circ} \mathrm{C}$ and controlled constantly humidity $(55 \%)$ with a $12 \mathrm{~h}$ light/dark cycle. The rats were ovariectomized surgically in Hormones Dept, NRC and were housed with ad libitum access to standard laboratory diet consisting of $10 \%$ casein, $4 \%$ salt mixture $4 \%$, $1 \%$ vitamin mixture, $10 \%$ corn oil and $5 \%$ cellulose, completed to $100 \%$ with corn starch (A.O.A.C., 1995). Animals were cared for according to the guidelines for animal experiments by the Ethical Committee of NRC.

The animals were classified into five groups of 10 rats each.

Group one: Gonad-intact control (nonovariectomized) group treated with the vehicle $(5 \%$ dimethylsulfoxide (DMSO) in saline) three times a week for 18 weeks, six months after starting of the experiment.

Group two: Ovariectomized control group treated with the vehicle (5\% DMSO in saline) three times a week for 18 weeks, six months after surgical operation.

Group three: Ovariectomized experimental rats, receiving DHEA (dissolved in 5\% DMSO in saline) orally three times a week in a dose of $250 \mathrm{mg} / \mathrm{Kg}$ body weight (Lardy et al., 1999) for 18 weeks, six months after surgical operation.

Group four: Ovariectomized rats serving as Al-intoxicated control group were injected i.p. with aluminum chloride $\left(\mathrm{AlCl}_{3}\right)$ dissolved in distilled water daily for 12 weeks in a dose of $4.2 \mathrm{mg} / \mathrm{Kg}$ body weight (Julk \& Gill 1996) three months after surgical operation and served as $\mathrm{Al}$-intoxicated control group.

Group five: Ovariectomized rats, injected i.p. with $\mathrm{AlCl}_{3}(4.2 \mathrm{mg} / \mathrm{kg}$ body weight) daily for 12 weeks, three months after ovarectomy. Then, they received DHEA orally in a dose of $250 \mathrm{mg} / \mathrm{Kg}$ body weight three times weekly for 18 weeks.

Brain tissue sampling and preparation. At the end of the experiment, the rats were fasted overnight, subjected to anesthesia with diethyl ether and sacrificed. The whole brain of each rat was rapidly dissected, washed with isotonic saline and dried on filter paper. Each brain was divided sagitally into two portions. The first portion was weighed and homogenized in ice-cold medium containing $50 \mathrm{mM}$ Tris/ $\mathrm{HCl}$ and 300 $\mathrm{mM}$ sucrose at $\mathrm{pH} 7.4$ to give a $10 \%$ (w/v) homogenate (Tsakiris et al., 2004). This homogenate was centrifuged at $1400 \times \mathrm{g}$ for $10 \mathrm{~min}$ at $4^{\circ} \mathrm{C}$. The supernatant was stored at $-80^{\circ} \mathrm{C}$ and used for biochemical analyses that included oxidative stress biomarkers $\left(\mathrm{H}_{2} \mathrm{O}_{2}, \mathrm{NO}\right.$ and MDA), antioxidant status (TAC, GSH, GPx, GR, SOD and CAT), antiapoptotic marker (Bcl-2), neurotrophic factor (BDNF) and cholinergic markers (AchE and Ach). Also, brain total protein concentration was measured to express the concentration of different brain parameters per $\mathrm{mg}$ protein. The second portion of the brain was fixed in $10 \%$ formalin for histological investigation.

The ethical conditions were applied such that the animals suffered no pain at any stage of the experiment and the study was approved by the Ethics Committee of the National Research Center. Animals were disposed of in bags provided by the Committee of Safety and Environmental Health, National Research Center.

Biochemical analyses. Brain hydrogen peroxide $\left(\mathrm{H}_{2} \mathrm{O}_{2}\right)$ level was determined by the spectrophotometric method according to Aebi (1984). The assay is based on the reaction of $\mathrm{H}_{2} \mathrm{O}_{2}$ in the presence of peroxidase with 3,5-dichloro-2-hydroxy-benzene sulfonic acid (DHBS) with 4-aminophenazone (AAP) to form a chromophore (quinoneimine dye). The color intensity of the chromophore) corresponds to the concentration of hydrogen peroxide in the sample which can be measured at $472 \mathrm{~nm}$.

Lipid peroxidation products represented by malondialdehyde (MDA) were evaluated by the method of Satoh (1978) using thiobarbituric acid (TBA) and measuring the reaction product spectrophotometrically at $534 \mathrm{~nm}$.

Brain nitric oxide (NO) level was assayed by the spectrophotometric method according to Berkels et al. (2004). Promega's griess reagent system is based on the chemical reaction between sulfanilamide and N-1-naphthylethylenediamine dihydrochloride under acidic condition (phosphoric acid) to give colored azo-compound which can be measured at 520-550 $\mathrm{nm}$.

Brain total antioxidant capacity was assayed according to the method of Koracevic et al. (2001). The method is based on determination of the ability to eliminate added hydrogen peroxide. The remaining $\mathrm{H}_{2} \mathrm{O}_{2}$ is determined colorimetrically by an enzymatic reaction converting 3,5-dichloro-2-hydroxyl benzenesulfonate to a colored product that is measured at $532 \mathrm{~nm}$.

Brain glutathione (GSH) was measured colorimetrically according to the method of Moron et al. (1979). This method is based on determination of the relatively stable yellow color when 5,5'-dithiobis-2-nitrobenzoic acid (DTNB) is added to sulfhydryl compounds which can be measured at $503 \mathrm{~nm}$.

Glutathione reductase (GR) was assayed colorimetrically according to the method of Erden and Bor (1984). The assay method is based on oxidation of NADPH which is followed at $340 \mathrm{~nm}$. One unit of activity is defined as the oxidation of 1 nmole $\mathrm{NADPH} / \mathrm{min} / \mathrm{mg}$ protein.

Glutathione peroxidase (GPx) was determined colorimetrically according to the method of Ozdemir et al. (2005) using NADPH-coupled reduction of GSSG catalyzed by GR which can be measured at $340 \mathrm{~nm}$.

Brain superoxide dismutase (SOD) activity was determined colorimetrically according to the method of Nishikimi et al. (1972). This assay relies on the ability of the enzyme to inhibit the phenazine methosulfate-mediated reduction of nitroblue tetrazolium dye which can be measured at $560 \mathrm{~nm}$.

Brain catalase (CAT) activity was determined colorimetrically according to the method of Aebi (1984). The assay is based on catalase-catalyzed reaction of a known quantity of $\mathrm{H}_{2} \mathrm{O}_{2}$ with DHBS and AAP to form a chromophore, which has a color intensity inversely proportional to the amount of catalase in the original sample which can be measured at $510 \mathrm{~nm}$.

Brain $\mathrm{Bcl}-2$ was detected by ELISA technique according to the method of Barbareschi et al. (1996). The assay utilizes an anti-Bcl-2 monoclonal antibody. Bcl-2 present in the sample binds to the antibody adsorbed to the microwells and a biotin-coniugated anti-Bcl-2 antibody is added to bind with $\mathrm{Bcl}-2$ captured by the first antibody. Then, the unbound biotin-conjugated anti-Bcl-2 is removed during a wash step. Then, streptavidin-HRP is added and bound to the biotin-conjugated anti-Bcl-2. 
Table 1. Effect of DHEA treatment on brain oxidative stress parameters in ovariectomized and Al-intoxicated ovariectomized rats.

\begin{tabular}{|c|c|c|c|}
\hline Parameters & $\begin{array}{l}\mathrm{H}_{2} \mathrm{O}_{2} \\
\text { ( } \mu \mathrm{mol} / \mathrm{mg} \text { protein) }\end{array}$ & $\begin{array}{l}\mathrm{NO} \\
(\mu \mathrm{mol} \backslash \mathrm{mg} \text { protein) }\end{array}$ & $\begin{array}{l}\text { MDA } \\
\text { (nmol/mg protein) }\end{array}$ \\
\hline Gonad-intact control & $6.90 \pm 0.32$ & $31.38 \pm 1.97$ & $5.60 \pm 0.30$ \\
\hline Ovariectomized control & $\begin{array}{l}9.30 \pm 0.40 \\
(34.8 \%)\end{array}$ & $\begin{array}{l}44.94 \pm 2.45^{a} \\
(43.3 \%)\end{array}$ & $\begin{array}{l}6.40 \pm 0.34 \\
(14.3 \%)\end{array}$ \\
\hline Ovariectomized + DHEA & $\begin{array}{l}7.87 \pm 0.36 \\
(-15.4 \%)\end{array}$ & $\begin{array}{l}35.137 \pm 1.88^{b} \\
(-21.8 \%)\end{array}$ & $\begin{array}{l}5.80 \pm 0.31 \\
(-9.4 \%)\end{array}$ \\
\hline Al-intoxicated control & $\begin{array}{l}34.00 \pm 1.86^{b} \\
(265.6 \%)\end{array}$ & $\begin{array}{l}86.40 \pm 3.61^{b} \\
(92.3 \%)\end{array}$ & $\begin{array}{l}9.60 \pm 0.40^{b} \\
(50 \%)\end{array}$ \\
\hline Ovariectomized + Al + DHEA & $\begin{array}{l}21.00 \pm 1.60 c \\
(-38.2 \%)\end{array}$ & $\begin{array}{l}60.20 \pm 3.09 c \\
(-30.3 \%)\end{array}$ & $\begin{array}{l}6.73 \pm 0.31^{c} \\
(-29.9 \%)\end{array}$ \\
\hline
\end{tabular}

Data are represented as mean \pm S.E. of 10 female rats/group. aSignificant change in comparison with gonad-intact control group. bSignificant change in comparison with ovariectomized control group. cSignificant change in comparison with Al-intoxicated control group. (\%) Percent of difference with respect to corresponding control value.

Following incubation, unbound strepavidin-HRP is removed during a wash step and the substrate solution reacting with HRP is added to the wells. A colored product is formed proportionally to the amount of Bcl-2 present in the sample or the standards. The reaction is terminated by addition of acid and light absorbance is measured at $450 \mathrm{~nm}$.

Brain BDNF was detected by ELISA technique according to the method of Barakat-Walter (1996). The assay is based on monoclonal antibody specific for BDNF precoated onto a microplate. When the standard and samples are pipetted into the wells, any BDNF present is bound by the immobilized antibody. Then, the enzyme-linked monoclonal antibody specific for BDNF is added to the wells and, following a wash to remove any unbound antibody enzyme, a substrate solution are added to the wells. The color develops in proportion to the amount of BDNF bound in the initial step. The color development is stopped and the intensity of the color can be measured at $450 \mathrm{~nm}$.

Brain AchE was determined colorimetrically according to the method of Den Blaauwen et al. (1983). The method is based on acetylcholinesterase hydrolyzing acetylcholine to acetate and thiocholine, which in the presence of dithiobis-nitrobenzoate produces 2-nitromercapto-benzaote which can be measured at $405 \mathrm{~nm}$.

Brain Ach level was measured colorimetrically according to the method of Oswald et al. (2008). The assay method is based on oxidation of free choline to betaine via the intermediate betaine aldehyde. The reaction generates products which can be measured at $570 \mathrm{~nm}$.

Quantitative estimation of brain homogenate total protein was carried out according to the method of Lowry et al. (1951).

Histological examination. The brain tissue was fixed in $10 \%$ formalin for one week, washed in running tap water for $24 \mathrm{~h}$ and dehydrated in ascending series of ethanol (50-90\%), followed by absolute alcohol. The samples were cleared in xylene and immersed in a mixture of xylene and paraffin at $60^{\circ} \mathrm{C}$. The tissue was then transferred to pure paraffin wax of the melting point $58^{\circ} \mathrm{C}$ and then mounted in blocks and left at $4{ }^{\circ} \mathrm{C}$. The paraffin blocks were sectioned on a microtome at thickness of $5 \mu \mathrm{m}$ and mounted on clean glass slides and left in the oven at $40^{\circ} \mathrm{C}$ to dryness. The slides were deparafinized in xylene and then immersed in descending series of ethanol $(90-50 \%)$. The ordinary haematoxylin and eosin stain was used to stain the slides (Drury and Wallington, 1980).

Statistical analysis. The results were expressed as means \pm standard error of the mean (SE). Data were analyzed by one way analysis of variance (ANOVA) using the Statistical Package for the Social Science (SPSS) program, version 11 followed by least significant difference (LSD) to compare significance between groups (Armitage and Berry, 1987). Difference was considered significant at $P \leq 0.05$.

\section{RESULTS}

The results in Table 1 show the effect of DHEA on brain oxidative stress markers represented by $\mathrm{H}_{2} \mathrm{O}_{2}$, nitric oxide and MDA levels in ovariectomized and $\mathrm{Al}$ intoxicated ovariectomized rats. Ovariectomized control rats showed significant increase in brain $\mathrm{H}_{2} \mathrm{O}_{2}$, nitric oxide and MDA levels when compared to gonad-intact

Table 2. Effect of DHEA treatment on brain antioxidant status in ovariectomized and Al-intoxicated ovariectomized rats.

\begin{tabular}{|c|c|c|c|c|c|c|}
\hline Parameters & $\begin{array}{l}\text { TAC } \\
\text { (mmol/mg } \\
\text { protein) }\end{array}$ & $\begin{array}{l}\text { GSH } \\
\text { (U /mg } \\
\text { protein) }\end{array}$ & $\begin{array}{l}\text { GPX } \\
\text { U/mg } \\
\text { protein) }\end{array}$ & $\begin{array}{l}\text { GR } \\
\text { U/mg } \\
\text { protein) }\end{array}$ & $\begin{array}{l}\text { SOD } \\
\text { (U/mg } \\
\text { protein) }\end{array}$ & $\begin{array}{l}\text { CAT } \\
\text { (U/mg } \\
\text { protein) }\end{array}$ \\
\hline Gonad-intact control & $14.20 \pm 0.81$ & $34.00 \pm 2.12$ & $1.23 \pm 0.01$ & $12.00 \pm 1.21$ & $2.81 \pm 0.18$ & $5.79 \pm 0.31$ \\
\hline Ovariectomized control & $\begin{array}{l}8.86 \pm 0.43^{a} \\
(-37.6 \%)\end{array}$ & $\begin{array}{l}21.90 \pm 1.10^{a} \\
(-35.6 \%)\end{array}$ & $\begin{array}{l}1.00 \pm 0.01^{a} \\
(-18.7 \%)\end{array}$ & $\begin{array}{l}6.44 \pm 0.98^{a} \\
(-46.3 \%)\end{array}$ & $\begin{array}{l}2.06 \pm 0.19 a \\
(-26.6 \%)\end{array}$ & $\begin{array}{l}4.95 \pm 0.29 \\
(-14.6 \%)\end{array}$ \\
\hline Ovariectomized + DHEA & $\begin{array}{l}9.52 \pm 0.51 \\
(7.4 \%)\end{array}$ & $\begin{array}{l}29.60 \pm 1.78 b \\
(35.2 \%)\end{array}$ & $\begin{array}{l}1.13+0.05^{b} \\
(13.0 \%)\end{array}$ & $\begin{array}{l}8.66 \pm .029 \mathrm{~b} \\
(34.5 \%)\end{array}$ & $\begin{array}{l}2.40 \pm 0.10 \\
(16.4 \%)\end{array}$ & $\begin{array}{l}5.40 \pm 0.29 \\
(9.1 \%)\end{array}$ \\
\hline Al-intoxicated control & $\begin{array}{l}6.33 \pm 0.35^{b} \\
(-28.6 \%)\end{array}$ & $\begin{array}{l}20.10 \pm 1.45^{b} \\
(-8.2)\end{array}$ & $\begin{array}{l}0.90 \pm 0.03^{b} \\
(-10.0 \%)\end{array}$ & $\begin{array}{l}5.23 \pm 0.25^{b} \\
(-18.8 \%)\end{array}$ & $\begin{array}{l}1.80 \pm 0.17 \\
(-12.7 \%)\end{array}$ & $\begin{array}{l}4.16 \pm 0.26 \\
(-16.0 \%)\end{array}$ \\
\hline Ovariectomized + Al +DHEA & $\begin{array}{l}9.36 \pm 0.52^{c} \\
(47.9 \%)\end{array}$ & $\begin{array}{l}28.99 \pm 1.20^{c} \\
(44.2 \%)\end{array}$ & $\begin{array}{l}1.10 \pm 0.09 c \\
(22.2 \%)\end{array}$ & $\begin{array}{l}9.10 \pm 0.22^{c} \\
(74.0 \%)\end{array}$ & $\begin{array}{l}2.10 \pm 0.18 \\
(16.7 \%)\end{array}$ & $\begin{array}{l}5.17 \pm 0.32^{c} \\
(24.4 \%)\end{array}$ \\
\hline
\end{tabular}

Data are represented as mean \pm S.E. of 10 female rats/group. aSignificant change in comparison with gonad-intact control group. bSignificant change in comparison with ovariectomized control group. 'Significant change in comparison with Al-intoxicated control group. (\%) Percent of difference with respect to corresponding control value. 
Table 3. Effect of DHEA treatment on brain antiapoptotic marker $(\mathrm{BCl}-2)$ and neurotrophic factor (BDNF) in ovariectomized and Alintoxicated ovariectomized rats.

\begin{tabular}{|c|c|c|}
\hline Parameters & $\begin{array}{l}\text { Bcl-2 } \\
\text { (pg/mg protein) }\end{array}$ & $\begin{array}{l}\text { BDNF } \\
\text { (pg/mg protein) }\end{array}$ \\
\hline Gonad-intact control & $115.00 \pm 5.74$ & $88.26 \pm 3.31$ \\
\hline Ovariectomized control & $\begin{array}{l}69.00 \pm 3.00^{a} \\
(-40.0 \%)\end{array}$ & $\begin{array}{l}62.38 \pm 3.15^{a} \\
(-29.3 \%)\end{array}$ \\
\hline Ovariectomized + DHEA & $\begin{array}{l}82.30 \pm 2.40^{b} \\
(19.3 \%)\end{array}$ & $\begin{array}{l}75.11 \pm 2.94^{b} \\
(20.4 \%)\end{array}$ \\
\hline Al-intoxicated control & $\begin{array}{l}58.20 \pm 3.70^{b} \\
(-15.6 \%)\end{array}$ & $\begin{array}{l}45.50 \pm 2.49 b \\
(-27.1 \%)\end{array}$ \\
\hline $\begin{array}{l}\text { Ovariectomized + Al } \\
+ \text { DHEA }\end{array}$ & $\begin{array}{l}73.8 \pm 3.17 c \\
(26.7 \%)\end{array}$ & $\begin{array}{l}58.51 \pm 3.06 \\
(28.6 \%)\end{array}$ \\
\hline
\end{tabular}

Data are represented as mean \pm S.E. of 10 rats/group. aSignificant change in comparison with gonad-intact control group. bSignificant change in comparison with ovariectomized control group. cSignificant change in comparison with Al-intoxicated control group. (\%) Percent of difference with respect to corresponding control value.

control group. On the other hand, treatment of ovariectomized rats with DHEA recorded significant decrease in brain $\mathrm{NO}$ and insignificant reduction in brain $\mathrm{H}_{2} \mathrm{O}_{2}$ and MDA levels as compared with ovariectomized control group. In addition, daily administration of $\mathrm{AlCl}_{3}$ to ovariectomized rats showed significant elevation in all oxidative stress biomarkers $\left(\mathrm{H}_{2} \mathrm{O}_{2}, \mathrm{NO}\right.$ and MDA) when compared to ovariectomized control group. Treatment of Al-intoxicated ovariectomized rats with DHEA produced significant reduction in brain $\mathrm{H}_{2} \mathrm{O}_{2}$, NO and MDA levels when compared with Al-intoxicated control rats.

The data in Table 2 demonstrate that ovariectomy induced significant reduction in brain TAC, GSH, GPx, GR and SOD activities in comparison with gonad-intact control group. Brain CAT activity was decreased insignificantly by ovariectomy as compared to gonad-intact control group.

On the other hand, treatment of ovariectomized rats with DHEA induced significant enhancement in brain GSH, GPx and GR, and insignificant increase in brain SOD and CAT activities when compared to those in ovariectomized control rats. In comparison with ovariectomized control rats, daily administration of $\mathrm{AlCl}_{3}$ in ovariectomized rats induced significant reduction in brain TAC, GSH, GPx and GR and insignificant inhi-

Table 4. Effect of DHEA treatment on brain acetylcholinesterase (AchE) and acetylcholine (Ach) in ovariectomized and Al-intoxicated ovariectomized rats.

\begin{tabular}{|c|c|c|}
\hline Parameters & $\begin{array}{l}\text { Ach } \\
(\mu \mathrm{mol} / \mathrm{mg} \text { protein })\end{array}$ & $\begin{array}{l}\text { AchE } \\
\text { (U/mg protein) }\end{array}$ \\
\hline Gonad-intact control & $85.00 \pm 3.42$ & $568.96 \pm 26.11$ \\
\hline Ovariectomized control & $\begin{array}{l}81.00 \pm 3.25 \\
(-4.7 \%)\end{array}$ & $\begin{array}{l}608.55 \pm 33.75 \\
(7.0 \%)\end{array}$ \\
\hline Ovariectomized + DHEA & $\begin{array}{l}83.7 \pm 2.63 \\
(3.3 \%)\end{array}$ & $\begin{array}{l}591.60 \pm 32.27 \\
(-2.8 \%)\end{array}$ \\
\hline Al-intoxicated control & $\begin{array}{l}60.00 \pm 2.55^{b} \\
(-25.9 \%)\end{array}$ & $\begin{array}{l}858.30 \pm 43.82^{b} \\
(41.0 \%)\end{array}$ \\
\hline $\begin{array}{l}\text { Ovariectomized + Al } \\
+ \text { DHEA }\end{array}$ & $\begin{array}{l}74.20 \pm 3.45^{c} \\
(23.7 \%)\end{array}$ & $\begin{array}{l}727.75 \pm 37.03^{c} \\
(-15.2 \%)\end{array}$ \\
\hline
\end{tabular}

Data are represented as mean \pm S.E. of 10 rats/group. bSignificant change in comparison with ovariectomized control group. 'Significant change in comparison with Al-intoxicated control group. (\%) Percent of difference with respect to corresponding control value bition in brain SOD and CAT. However, treatment of Al-intoxicated ovariectomized rats with DHEA produced significant elevation in brain TAC, GSH, GPx, GR and CAT activities and insignificant increase in brain SOD activity as compared to Al-intoxicated control rats.

The results in Table 3 show that ovariectomy resulted in significant decrease in brain levels of Bcl-2 and $\mathrm{BDNF}$ in comparison with gonad-intact control group. On the other hand, treatment of ovariectomized rats with DHEA produced significant increase in brain Bcl2 and BDNF levels when compared with those in ovariectomized control group. Administration of $\mathrm{AlCl}_{3}$ in ovariectomized rats led to significant reduction in brain Bcl-2 as well as BDNF levels as compared with those in ovariectomized control rats. The treatment of Al-intoxicated ovariectomized rats with DHEA caused significant increase in brain Bcl-2 and BDNF levels in comparison with Al-intoxicated control group.

The data in Table 4 demonstrate that ovariectomy caused insignificant increase in brain AchE activity and insignificant decrease in brain Ach level in comparison with gonad-intact control group. The treatment of ovariectomized rats with DHEA revealed insignificant decrease in brain AchE activity accompanied with insignificant increase in brain Ach level in comparison with ovariectomized control group. Aluminum administration in ovariectomized rats induced significant elevation in brain AchE activity and significant reduction in brain Ach level as compared with ovariectomized control rats. Treatment of Al-intoxicated ovariectomized rats with DHEA produced significant decrease in brain AchE activity accompanied with significant increase in brain Ach level in comparison with Al-intoxicated control group.

Microscopic examination of brain sections of gonadintact control rats (Fig. 1A) showed normal morphological structure of the hippocampus. Microscopic examination of brain of ovariectomized control rats (Fig. 1B) showed normal morphological structure of the hippocampus. Also microscopic examination of hippocampus of ovariectomized rats administrated with DHEA showed normal morphological structure (Fig. 1C). On the other hand, microscopic investigation of brain sections of ovariectomized Al-intoxicated rats demonstrated amyloid plaques of various sizes in the cerebral cortex and in the hippocampus (Fig. 1D). Histological investigation of brain section of Al-intoxicated ovariectomized rats treated with DHEA revealed more or less normal structure in the hippocampus, i.e., all amyloid plaques that were formed under the influence of ovariectomy combined with $\mathrm{AlCl}_{3}$ administration disappeared following the treatment with this hormone (Fig. 1E).

\section{DISCUSSION}

There is growing evidence that oxidative stress and estrogen deprivation after menopause or ovariectomy represent two main risk factors closely related to the development of Alzheimer's disease (Behl \& Moosmann, 2002). Furthermore, aluminum has been implicated in aging-related changes and particularly in neurodegenerative diseases as it promotes the formation of $\beta$-amyloid plaques (Bharathi et al., 2008).

The present results demonstrate that there was significant elevation in brain $\mathrm{H}_{2} \mathrm{O}_{2}, \mathrm{NO}$ and MDA levels of ovariectomized rats administered with $\mathrm{AlCl}_{3}$. Tuneva et al. (2006) demonstrated an increase in ROS, including $\mathrm{H}_{2} \mathrm{O}_{2}$ production in different brain areas due to $\mathrm{Al}$ exposure. 

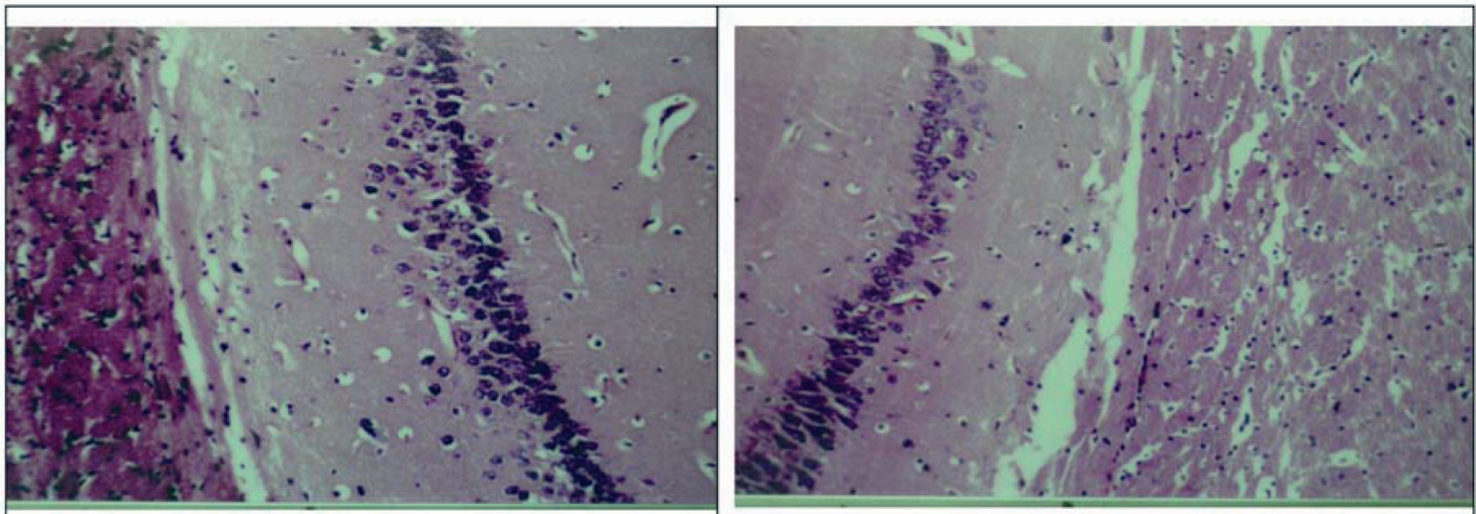

(A)

(B)

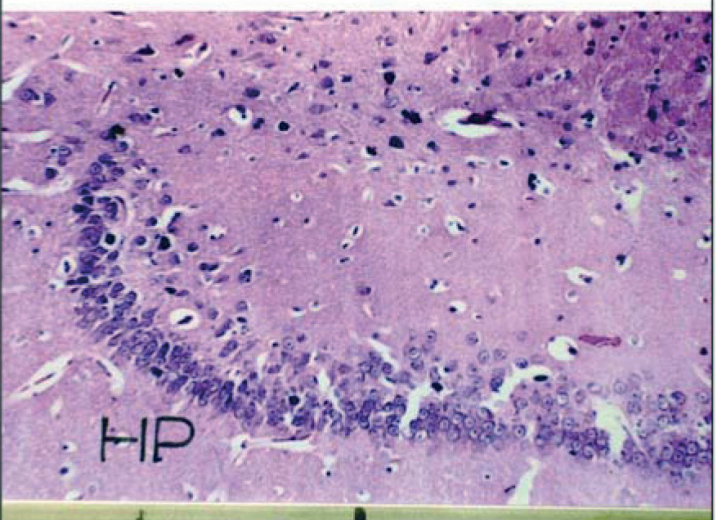

(C)

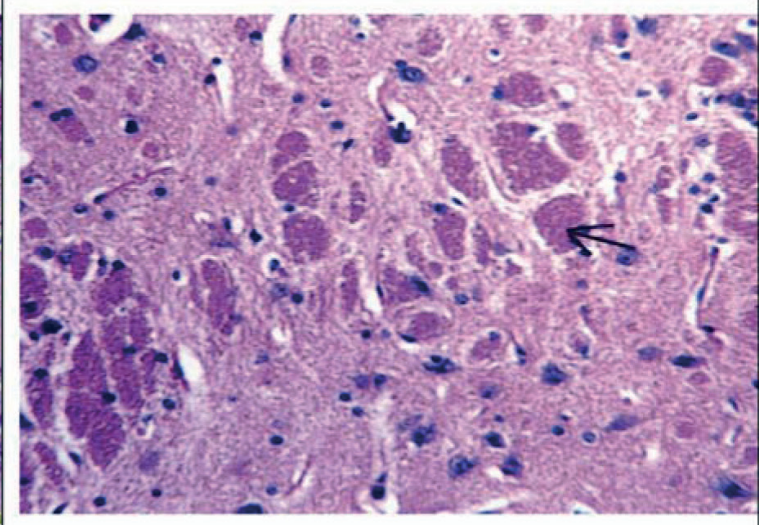

(D)

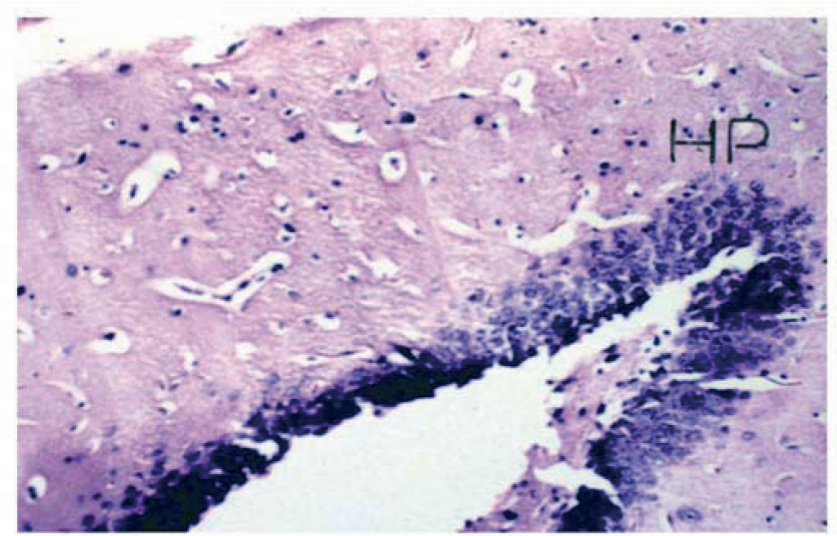

(E)

Figure 1. Micrographs of brain sections.

Magnification x 40. (A) Gonad-intact control showing normal morphological structure of the hippocampus. (B) Ovariectomized control rat showing normal morphological structure of the hippocampus. (C) DHEA treated ovariectomized rat showing normal morphological structure of the hippocampus (HP). (D) Al-intoxicated ovariectomized rat showing various sizes of amyloid plaques (arrow) in the cerebral cortex and hippocampus (HP). (E) Al-intoxicated ovariectomized rat treated with DHEA showing normal morphological structure of the hippocampus (HP).

Also, $\mathrm{Al}$ could increase the activity of monoamine oxidase (MAO) in the brain, which leads to increased generation of $\mathrm{H}_{2} \mathrm{O}_{2}$ (Huh et al., 2005). Aluminum could induce lipid peroxidation and alter the physiological and biochemical behavior of the living organism, a matter implicated in the increased brain MDA level (Kumar et al., 2008). The finding of significant elevation of brain $\mathrm{NO}$ level after $\mathrm{AlCl}_{3}$ administration in ovariectomized rats is in agreement with the previous studies of the Garrel et al. (1994) and Guix et al. (2005). The NO elevation in brain tissue may be related to Al-induced nitric oxide synthase (NOS) activity with consequent increase in $\mathrm{NO}$ production in rat brain tissue and microglial cells (Guix et al., 2005). Those authors found that cerebellar levels of inducible NOS (iNOS) protein in rats was significantly elevated following both shortand long-term $\mathrm{Al}$ administration. 
It is obvious that treatment of Al-intoxicated ovariectomized rats with DHEA produced significant decrease in brain $\mathrm{H}_{2} \mathrm{O}_{2}$ and MDA levels. These remarkable effects of DHEA may be related to DHEA inhibiting the monoamine oxidase (MAO) activity in brain. Considering the important role attributed to MAO activity in the generation of $\mathrm{H}_{2} \mathrm{O}_{2}$ (Marklund et al., 1982), the inhibitory effect of DHEA on MAO activity can be regarded as a mechanism by which DHEA could reduce oxidative stress, production of $\mathrm{H}_{2} \mathrm{O}_{2}$ and lipid peroxidation ( $\mathrm{Ku}-$ mar et al., 2008).

The present results also revealed a marked decrease in brain NO level as a result of DHEA administration in ovariectomized and Al-intoxicated ovariectomized rats. DHEA has been found to inhibit NMDA-induced NO production and NO synthase (NOS) activity in hippocampus cell culture (Kurata et al., 2004).

Considering total antioxidant activity (TAC) and antioxidant enzyme activities, ovariectomized rats exhibited significant decrease in brain TAC. Oxidative stress resulting from ovariectomy might cause depression in the antioxidant enzyme activities and in gene expression necessary to maintain normal brain functioning (Vina et al., 2008). Also, significant decrease in brain TAC level was observed in Al-intoxicated ovariectomized rats. Aluminum has been shown to induce lipid peroxidation with depletion of several antioxidant enzymes (Mahieu et al., 2009). Long term exposure to oxidative stress due to $\mathrm{Al}$ exposure leads to exhaustion of antioxidative enzymes.

DHEA administration revealed significant increase in brain TAC in Al-intoxicated ovariectomized rats. DHEA exhibits antioxidant properties in experimental systems (Aragno et al., 1999). Several explanations have been put forward for multitargeted antioxidant effects of DHEA, including its upregulating effect on catalase expression (Yildirim et al., 2003) and activity (Schwartz et al., 1988), as well as its activating action on the thioredoxin system (Gao et al., 2005). DHEA could also suppress superoxide anion production (Mohan \& Jacobson, 1993).

Remarkable decrease was recorded in brain GSH, GPx, GR,SOD and CAT activities in both ovariectomized rats and Al-intoxicated ovariectomized rats. Munoz-Castaneda et al. (2006) showed that the lack of estrogens by ovariectomy induced reduction of the antioxidant status (GSH, SOD and GPx) accompanied by elevated lipid peroxides in rats. A drastic depletion of brain GSH may be due to the increased cytotoxicity of $\mathrm{H}_{2} \mathrm{O}_{2}$ in endothelial cells as a result of inhibition of glutathione reductase (Yousif \& El-Rigal, 2004 and El- Rigal et al., 2006). The significant depletion of GR, GSH and GPx in brain of ovariectomized rats indicates the damage of the second line of antioxidant defense system. This probably further exacerbates oxidative damage via adverse affect on critical GSH-related processes. Reduced antioxidant status as a result of increased ROS production in experimental ovariectomy has been reported previously (Li et al., 2008; Yu et al., 2008). Aluminum exposure causes impairment of the antioxidant defense system that may lead to oxidative stress (Kumar et al., 2009a,b). Aluminum causes brain damage via ROS more than any other organ because of its high lipid content, high oxygen turnover, low mitotic rate as well as low antioxidant concentration (Di et al., 2006a). The study of Di et al. (2006b) suggested that lower SOD activity in the brain due to $\mathrm{Al}$ exposure may be due to the altered conformation of SOD molecule as a result of Al-SOD complex formation.
Administration of DHEA in ovariectomized and Alintoxicated ovariectomized rats showed detectable increase in brain GSH, GPx, GR, SOD and CAT activities. It has been reported that the natural steroid hormone dehydroepiandrosterone- $3 \beta$-sulfate (DHEAS) is a specific activator of peroxisome proliferator-activated receptor $\alpha(\operatorname{PPAR} \alpha)$ (Peters et al., 1996). Activation of PPAR $\alpha$ in vivo causes an upregulation of $\mathrm{mRNA}$ and protein levels of a number of peroxisomal and non-peroxisomeassociated enzymes and structural proteins, among them the antioxidant enzymes CAT and Cu, Zn-superoxide dismutase, as well as mediators of the glutathione pathway (Devchand et al., 1996).

Regarding the antiapoptotic marker (Bcl-2) and brainderived neurotrophic factor (BDNF) levels, the present data showed significant decrease in brain levels of Bcl2 and BDNF in ovariectomized rats and Al-intoxicated ovariectomized rats. Sharma and Mehra (2008) stated that ovariectomy decreased $\mathrm{Bcl}-2$ expression and increased proapoptotic marker (Bax) expression in the rat hippocampus. Altered $\mathrm{Bax} / \mathrm{Bcl}-2$ ratio is critical to $\mathrm{Al}$ induced apoptosis (Johnson et al., 2005) leading to activation of caspase- 3 and release of cytochrome c. Kumar et al. (2009b) reported that $\mathrm{Al}$ increases p53 protein expression by activating p38 MAPK to initiate apoptosis and this is accompanied by a marked inhibition of $\mathrm{Bcl}-2$ and increased Bax expression.

Takuma et al. (2007) showed marked decrease in the BDNF mRNA level in the hippocampus due to ovariectomy in mice. Disruption of the proinflamatory cytokine/neurotrophin balance by $\mathrm{Al}$ plays an important role in the neurodegenerative disease (Nagatsu et al., 2000).

DHEA administration in ovariectomized and Alintoxicated ovariectomized rats resulted in significant increase in brain Bcl-2 and BDNF levels. The mechanism by which DHEA could stimulate $\mathrm{Bcl}-2$ expression is that DHEA binds to and activates G-protein coupled membrane receptor alpha inhibitory subunit (Goi) that, in turn, activates protooncogenic tyrosine kinase c (Src), protein kinase $\mathrm{C}$ (PKC) and MAPK/ERK pathway. These kinases activate the prosurvival transcription factors CREB which stimulate the expression of antiapoptotic proteins such as Bcl-2 and Bcl-xl (Charalampopoulos et al., 2006). Therefore, DHEA could increase Bcl-2 level and stimulate Bcl-2 function. Several transcription factors contributing to the regulation of BDNF promoters have been characterized and CREB is one of them (Tabuchi et al., 2002).

With respect to cholinergic markers, the present results showed significant increase in brain activity of AchE with concomitant decrease in Ach level in both ovariectomized rats and Al-intoxicated ovariectomized rats. Zheng et al. (2009) reported increased AchE activity in Al-overloaded rats. Kaizer et al. (2008) suggested that $\mathrm{Al}$ exposure increased AchE activity via allosteric interaction between $\mathrm{Al}$ and the peripheral anionic site of the enzyme molecule, leading to the etiology of $\mathrm{AD}$ pathological deterioration. $\mathrm{Al}$ exerts cholinotoxic effects by blocking the provision of acetyl-CoA, which is required for Ach synthesis or by impairing the activities of choline acetyl transferase (ChAT) itself (Alleva et al., 1998).

The data in the current study revealed that DHEA administration produced significant decrease in brain AchE activity associated with significant increase in brain Ach level in Al-intoxicated ovariectomized rats. It has been demonstrated that DHEAS significantly increases Ach release in the hippocampus (Rhodes et al., 1996). Thus, the promoting effect of DHEAS on Ach release in the 
hippocampus may be one mechanism for its memoryenhancing effect (Zheng, 2009).

Microscopic examination of brain sections of ovariectomized rats showed that ovariectomy did not produce any histological changes in the hippocampus and this finding is in agreement with that of Van Groen and Kadish (2005). On the other hand, microscopic investigation of brains of $\mathrm{Al}$-intoxicated ovariectomized rats revealed the presence of $\beta$-amyloid plaques in the cerebral cortex and the hippocampus. In accordance with our results, Abd El-Rahman (2003) demonstrated that $\mathrm{Al}$ administration causes the appearance of neuritic plaques with dark a center in the hippocampus, typical for the Alzheimer's disease.

Treatment of $\mathrm{Al}$-intoxicated ovariectomized rats with DHEA revealed more or less normal structure of the hippocampus, i.e., most of $\beta$-amyloid plaques that were formed under the effect of $\mathrm{AlCl}_{3}$ administration disappeared under the influence of this hormone. This result is in agreement with Cardounel et al. (1999) who observed that DHEA can protect against $\beta$-amyloid toxicity in hippocampal cells.

In summary, the present study demonstrates significant increase in brain oxidative stress parameters and significant decrease in brain TAC, antioxidant enzyme activities, brain Bcl-2 and BDNF levels in Al-intoxicated ovariectomized rats. Also, significant decrease in brain Ach level accompanied with significant increase in brain AchE activity were detected in Al-intoxicated ovariectomized rats. Microscopic investigation of brain sections of Al-intoxicated ovariectomized rats demonstrated formation of $\beta$-amyloid plaque in the cerebral cortex and in the hippocampus. DHEA treatment produced significant amelioration in brain oxidative stress markers, activation of the antioxidant enzymes, enhancement of brain $\mathrm{Bcl}-2$, $\mathrm{BDNF}$ and acetylcholine levels. Histological investigation of brain sections of Al-intoxicated ovariectomized rats treated with DHEA revealed more or less normal structure of the hippocampus. Thus, it can be concluded that DHEA has a potent role in modulating the neurodegeneration characterizing AD through its antioxidant, antiapoptotic, neurotrophic properties and antiamyloidogenic effect as well as its cholinesterase -inhibiting activity.

\section{Acknowledgements}

The authors would like to thank Dr. Abdel-Razik A. Farrag, Assistant Professor of Histology and Histochemistry, Department of Pathology, National Research Center, Giza, for his kind cooperation in histological investigations included in the present study.

\section{REFERENCES}

Abd El-Rahman SS (2003) Neuropathology of aluminum toxicity in rats (glutamate and GABA impairment). Pharmacol Res 47: 189-194.

Aebi H (1984) Catalase in vitro. Methods Enzymol 105: 121-126.

Alleva K, Rankin J, Santucci D (1998) Neurobehavioural alteration in rodents following developmental exposure to aluminum. Toxicol Ind Health 14: 209-221.

Aragno M, Tamagno E, Gatto V, Brignardello E, Parola S, Danni O, Boccuzzi G (1999) Dehydroepiandrosterone protects tissues of streptozotocin-treated rats against oxidative stress. Free Radic Biol Med 26: 1467-1474.

Armitage P, Berry G (1987) Comparison of several groups. In: Statistical methods in medical research, 2nd edn, pp 186-213. Blockwell Significant Publication, Oxford.

Barakat-Walter I (1996) Brain derived neurotrophic factor like immunoreactivity is localized mainly in small sensory neurons of rat dorsal root ganglia. J Neurosci Meth 68: 281-288.
Barbareschi M, Caffo O, Veronese S, Leek RD, Fina P, Fox S, Bonzanini M, Girlando S, Morelli L, Eccher C, Pezzella F, Doglioni C, Palma PD, Harris A (1996) Bcl-2 and P53 expression in nodenegative breast carcinoma: a study with long-term follow-up. Human Pathol 27: 1149-1155.

Behl C, Moosmann B (2002) Oxidative nerve cell death in Alzheimer's disease and stroke: antioxidants as neuroprotective compounds. Biol Chem 383 : 521-536.

Berkels R, Purol-Schnabel S, Roesen R (2004) Measurment of nitric oxide by reconversion of nitrate/nitrite to nitric oxide. Methods Mol Biol 279: 1-8.

Bharathi P, Vasudevaraju P, Govindaraju M, Palanisamy AP, Sambamurti K, Rao KS (2008) Molecular toxicity of aluminum in relation to neurodegeneration. Ind. I Med Res 128: 545-556.

Cardounel A, Regelson W, Kalimi M (1999) Dehydroepi-androsterone protects hippocampal neurons against neurotoxin-induced cell death: mechanism of action. Proc Soc Exp Bio Med 222: 145-149.

Charalampopoulos I, Alexaki VI, Lazaridis I, Dermitzaki E, Avlonitis N, Tsatsanis C, Calogeropoulou T, Margioris AN, Castanas E, Gravanis A, (2006) G-protein-associated, specific membrane binding sites mediate the neuroprotective effect of dehydroepiandrosterone. FASEB J 20: 577-579.

Den Blaauwen DH, Poppe WA, Tritschler W (1983) Acetylcholinesterase with acetylthiocholine iodide as substrate: references depending on age and sex with special reference to hormonal effects and pregnancy. J Clin Chem Clin Biochem 21: 381-386.

Devchand PR, Keller H, Peters JM, Vazquez M, Gonzalez FJ, Wahli W (1996) The PPAR $\alpha$-leukotriene B4 pathway to inflammation control. Nature 384: 39-43.

Di J, Yao K,Han W, Bi S, (2006a) Study on the interaction of copper zinc superoxide dismutase with aluminum ions by electrochemical and fluorescent method. Spectrochim Acta Mol Biomol Spectr 65: 896900 .

Di J, Zhang M, Yao K, Bi S (2006b) Direct voltammetery of catalase immobilized on silica sol-gel and cysteine modified gold electrode and its application. Biosen Bioelect 22: 247-252.

Drury RAB, Wallington EA (1980) Carleton's histological technique, 5th edn, pp 188-189, 237-240, 290-291. Oxford University Press, Oxford, New York, Toronto.

El-Rigal NS, Aly SA, Rizk MZ, Said,AA (2006) Effect of Ailanthus altissima and Ziziphus spina Christi extracts on some hepatic marker enzymes and antioxidants in Shistosoma mansoni infected mice. Pol J Food Nutr Sci 15/56: 199-206.

Erden M, Bor NM (1984) Changes in reduced glutathione, glutathione reductase and glutathione peroxidase after radiation in guinea pigs, Biochem Med 31: 217-227.

Gao J, Sun HY, Zhu ZR, Ding Z, Zhu L (2005) Antioxidant effects of dehydroepiandrosterone are related to upregulation of thioredoxin in SH-SY5Y cells. Acta. Biochim. Biophys Sin 37: 119-125.

Garrel C, Lafond JL, Guiraud P, Faure P, Favier A (1994) Induction of production of nitric oxide in microglial cells by insoluble form of aluminum. Ann New York Acad. Sci 738: 455-461.

Goel RM, Cappola AR (2011) Dehydroepiandrosterone sulfate and postmenopausal women. Curr Opin Endocrinol Diabetes Obes (in press). Grosgen S,Grimm MO, Frieb P, Hartmann T (2010) Role of amyloidbeta in lipid homeostasis. Biochim Biophys Acta 1801: 966-974.

Guix FX, Uribesalgo I, Coma M, Munoz FJ (2005) The physiology and pathophysiology of nitric oxide in the brain. Progress in Neurobiol 76: 126-152.

Huh JW, Choi M M, Lee JH, Yang SJ, Kim MJ, Choi J, Lee KH, Lee JE, Cho SW (2005) Activation of monoamine oxidase isotypes by prolonged intake of aluminum in rat brain. J Inorg Biochem 99: 2088-2091.

Johnson VJ, Kim S, Sharma RP (2005) Aluminum maltolate induces apoptosis and necrosis in neuro-2a cells: potential role for p53 signaling. Toxicol Sci 83: 329-339.

Julka D, Gill KD (1996) Effect of aluminum on regional brain antioxidant defense status in wistar rats. Res Exp Med 196: 187-194.

Kaizer RR,Correa MC, Gris LRS, Da Rosa CS, Bohrer D,Morsch VM, Rosa M, Schetinger C (2008) Effect of long term exposure to aluminum on the acetylcholinesterase activity in the central nervous system and erythrocytes. Neurochem Res 33: 2294-2301.

Koracevic D,Koracevic G, Djordjevic V, Andrejevic S, Cosic V (2001) Method for the measurement of antioxidant activity in human fluids. J Clin Pathol 54: 356-361.

Krysiak R, Frysz-Naglak D, Okopie B (2008) Current views on the role of dehydroepiandrosterone in physiology, pathology and therapy. Pol Merk Lek 24: 66-71.

Kumar P, Taha A, Sharma D, Kale RK, Baquer NZ (2008) Effect of dehydroepiandrosterone (DHEA) on monoamine oxidase activity, lipid peroxidation and lipofuscin accumulation in aging rat brain regions. Biogerontol 9: 235-246.

Kumar V, Bal A, Gill K.D. (2009a) Susceptibility of mitochondrial superoxide dismutase to aluminum-induced oxidative damage. Toxicol 255: $117-123$. 
Kumar V, Bal A, Gill KD (2009b) Aluminum-induced oxidative DNA damage recognition and cell cycle disruption in different regions of rat brain. Toxicol 264: 137-144.

Kurata K, Takebayashi M, Morinobu S, Yamawaki S (2004) Beta-estradiol, dehydroepiandrosterone, and dehydroepiandrosterone sulfate protect against N-methyl-D-aspartate-induced neurotoxicity in rat hippocampal neurons by different mechanisms. J Pharmacol Exp Ther 311: $237-245$.

Lardy H, Henwood SM, Weeks CE (1999) An acute oral gavage study of $\beta$-acetoxyandrost-5-ene-7, 17-dione (7-oxo-DHEA-acetate) in rats. Biochem Biophys Res Commun 254: 120-123.

Lazaridis I, Charalampopoulos I, Alexaki VI, Avlonitis N, Pediaditakis I, Efstathopoulos P, Calogeropoulou T, Castanas E, Gravanis A (2011) Neurosteroid dehydroepiandrosterone interacts with nerve growth factor (NGF) receptors, preventing neuronal apoptosis. PLoS Biol 9: 100-105.

Li W, Ota K, Nakamura J, Naruse K, Nakashima E, Oisa Y, Hamada Y (2008) Antiglycation effect of gliclazide on in vitro AGE formation from glucose and methylglyoxal. Exp Biol Med 23: 176-179.

Lowry OH, Rosebrough NJ, Farr A L, Randall RJ (1951) Protein measurement with the folin phenol reagent. J Biol Chem 193: 265-275.

Luppi C, Fioravanti M, Bertolini B, Inguscio M, Grugnetti A, Guerriero F, Rovelli C, Cantoni F,Guagnano P, Marazzi E, Rolfo E, Ghianda D, Levante D,Guerrini C,Bonacasa R, Solerte SB (2009) Growth factors decrease in subjects with mild to moderate Alzheimer's disease (AD): potential correction with dehydroepiandrosterone sulphate (DHEAS). Arch Gerontol Geriat 1: 173-184.

Mahieu S, Contini MD, Gonzez M, Millen N (2009) Melatonin reduces oxidative damage-induced by aluminum in rat kidney. Toxicol Lett 190: 9-15.

Marklund SL, Westman NG, Lundgren E, Roos G (1982) Copperand zinc-containing superoxide dismutase, manganese-containing superoxide dismutase, catalase, and glutathione peroxidase in normal and neoplastic human cell lines and normal human tissues. Cancer Res 42: 1955-1961.

Mohan PF, Jacobson MS (1993) Inhibition of macrophage superoxide generation by dehydroepiandrosterone. Am J Med. Sci 306: 10-15.

Moron MS, Depierre JW, Mannervik B (1979) Level of glutathione, glutathione reductase and glutathion- $S$-transferase activities in rat lung and liver. Biochem Biophys Acta 582: 67-68.

Munoz-Castaneda JR, Muntane J, Munoz MC, Bujalance I, Montilla P, Tunez I (2006) Estradiol and catecholestrogens protect against adriamycin-induced oxidative stress in erythrocytes of ovariectomized rats. Toxicol Lett 160: 196-203.

Nagatsu T, Mogi M, Ichinose H, Togari A (2000) Changes in cytokines and neurotrophins in Parkinson's disease. J Neural Transm 20: 277290.

Nishikimi M, Appaji N, Yagi K (1972) The occurrence of superoxide anion in the reaction of reduced phenazine methosulfate and molecular oxygen. Biochem. Biophys Res Commun 46: 849-854.

Oswald C, Smits SH, Hoing M, Sohn-Bosser L, Dupont L, Le Rudulier D, Schmitt L, Bremer E (2008) Crystal structures of choline/ acetylcholine substrate-binding protein chox from sinorhizobium meliloti in the liganded and unliganded-closed states. J Biol Chem 283: 32848-32859.

Ozdemir G, Ozden M, Maral H, Kuskay S, Cetinalp P ( 2005) Malondialdehde, glutathione, glutathione peroxidase and homocysteine levels in type 2 diabetic patients with and without microalbuminuria . Ann Clin Biochem. 42: 99-104.

Peters JM, Zhou YC, Ram P A, Lee SST, Gonzalez FJ, Waxman DJ (1996) Peroxisome proliferators-activated receptor $\alpha$ required for gene induction by dehydroepiandrosterone-3- $\beta$-sulfate. Mol Pharmacol 50: $67-74$.

Rhodes ME, Li PK, Flood JF, Johnson DA (1996) Enhancement of hippocampal acetylcholine release by the neurosteroid dehydroepiandrosterone sulfate: an in vivo microdialysis study. Brain Res 733: 284-286.

Satoh K (1978) Serum lipid peroxide in cerebrovascular disorders determined by a new colorimetric method. Clin Chim Acta 90: 37-43.

Schwartz AG, Whitcomb JM, Nyce JW, Lewbart ML, Pashko LL (1988) Dehydroepiandrosterone and structural analogs: a new class of cancer chemopreventive agents. Adv Cancer Res 51: 391-425.

Sharma K, Mehra RD (2008) Long term administration of estrogen or tamoxifen to ovariectomized rats affords neuroprote-ction to hippocampal neurons by modulating the expression of Bcl-2 and Bax. Brain Res 1204: 1-15.

Tabuchi A, Sakaya H, Kisukeda T, Fushiki H, Tsuda M (2002) Involvement of an upstream stimulatory factor as well as cAMP responsive element binding protein in the activation of brain derived neurotrophic factor gene promoter. J. Biol Chem 277: 35920-35931.

Takuma K, Matsuo A, Himeno Y, Hoshina Y, Ohno Y, Funatsu Y, Arai S, Kamei H, Mizoguchi H, Nagai T, Koike K, Inoue M, Yamada K (2007) 17- $\beta$ estradiol attenuates hippocampal neuronal loss and cognitive dysfunction induced by chronic restraint stress in ovariectomized rats. Neuroscience 146: 60-68.

Tsakiris S, Schulpis KH, Marinou K, Behrakis P (2004) Protective effect of L-cysteine and glutathione on the modulated suckling rat brain $\mathrm{Na}^{+}, \mathrm{K}^{+}$-ATPase and $\mathrm{Mg}^{2+}$-ATPase activities induced by the in vitro galactosaemia. Pharmacol Res 49 : 475-479.

Tuneva J, Chittur S, Boldyrev AA, Birman I, Carpenter DO (2006) Cerebellar granule cell death induced by aluminum. Neurotoxicol Res 9: 297-304

Van Groen T, Kadish I (2005) Transgenic AD model mice, effects of potential anti-AD treatments on inflammation and pathology. Brain Res Rev 48: 370-378.

Vina J, Sastre J, Pallardo FV,Gambini J, Borras C (2008) Modulation of longevity-associated genes by estrogens or phytooestrogens. Biol Chem 389: 273-277.

Yildirim A, Gumus M, Dalga S, Sahin YN, Akcay F (2003) Dehydroepiandrosterone improves hepatic antioxidant systems after renal ischemia-reperfusion injury in rabbits. Ann Clin Lab Sci 33: 459464.

Walton JR, Wang MX (2009) APP expression, distribution and accumulation are altered by aluminum in a rodent model for Alzheimer's disease. J Inorg Biochem 103: 1548-1554.

Yousif MF, El-Rigal NS (2004) C-glycolsyl flavones O-glycosides of clerodendrum splendens G.Don. and antioxidants activity in schistosome-infected mice. Egypt J Biomed Sci 14: 128-137.

Yu BC, Chang CK, Ou HY, Cheng KC, Cheng JT (2008) Decreases of peroxisome proliferation-activated receptor delta expression in cardiomyopathy of streptozotocin-induced diabetic rats. Cardiovascular res 38: 257-261.

Zheng J, Yang JQ, He BC, Zhou QX, Yu HR, Tang Y, Liu BZ (2009) Berberine and total base from rhizoma coptis chinensis attenuate brain injury in an aluminum-induced rat model of neurodegenerative disease. Sand Med J 30: 760-766.

Zheng P (2009) Neuroactive steroid regulation of neurotransmitter release in the CNS: action, mechanism and possible significance. Progr Neurobiol 89: 134-152. 